\author{
Jurnal segara JURNAL SEGARA \\ http://ejournal-balitbang.kkp.go.id/index.php/segara \\ ISSN : 1907-0659 \\ e-ISSN : 2461-1166 \\ Accreditation Number: 766/AU3/P2MI-LIPI/10/2016
}

\title{
IDENTIFYING PRIORITY AREAS FOR COASTAL PROTECTION AROUND JAVA, INDONESIA
}

\author{
Jimy Kalther \& Akemi Itaya \\ Graduate School of Bioresources, Mie University \\ 1577 Kurima-machiya, Tsu, Mie 514-8507, Japan \\ Received: 27 May 2021; Revised: 2 Agustus 2021; Accepted: 31 August 2021
}

\begin{abstract}
Climate change-induced sea level rise will likely increase the severity of ongoing coastal disasters in Indonesia. The selection and concentration approach should be applied to minimize the costs of conservation when budgets are limited. Prioritizing is then effective in terms of cost effectiveness. We aimed to identify priority areas for coastal protection against sea level rise around Java, Indonesia, using the Marxan model. The model uses systematic planning to select prioritized areas for coastal protection. Three scenarios were developed based on ecological, economic, and disaster elements that were exacerbated by sea level rise. A scenario is defined as a particular simulation circumstance based on assumptions about extrinsic drivers, parameters, and the structure of the model. Coastline length, mangrove coverage, low-elevation area, fishpond area, human settlement area, and the area of zones with the potential for annual rainfall increases acquired from DIVA-GIS and WorldClim were set as environmental factors. There were 60 areas facing the coast among 117 areas. For those protection, it would be fairly costly. We were able to narrow that number down from $18.8 \%$ to $62.4 \%$ from 117 areas using our method. This might become very cost effective. The most prioritized areas were located in the northern region of Java. These areas can be a focus of preferential effort and funding for conservation. The results of this study will help to make the protection strategy based on not only the magnitude of damage but also the total perspective using public data that is relatively easy to obtain.
\end{abstract}

Keywords: Aquaculture, erosion, low elevation area, mangrove, marxan. 


\section{INTRODUCTION}

Climate change and associated disasters are among the most serious global issues facing humanity. Sea level rise created by climate change will increase the rates and severity of coastal flooding, degrade coastal fresh water supplies, accelerate coastal erosion, and magnify the impacts of other coastal and marine hazards (Nicholls et al., 2011). Sea level rise may also change the spatial distribution of vulnerable coastal ecosystems, such as mangroves and saltmarshes, and their provision of ecosystem goods and services (Arkema et al., 2013). Oppenheimer et al. (2019) showed that the global mean sea level is rising and the process is accelerating. Observations made with tide gauges and altimetry demonstrated an increase of $1.4 \mathrm{~mm} /$ year from 1901 to $1990,2.1 \mathrm{~mm} /$ year from 1970 to 2005 , and $3.6 \mathrm{~mm} /$ year from 2006 to 2015. Relative to levels for the period 1986-2005, the sea level is projected to rise through the end of the century by $0.43 \mathrm{~m}(0.29-0.59 \mathrm{~m})$ under Representative Concentration Pathway (RCP) 2.6, and by $0.84 \mathrm{~m}$ (0.61-1.10 m) under RCP8.5 (Oppenheimer et al., 2019). Even though sea level rise is not always a direct trigger of coastal erosion, rising water levels undoubtedly lead to more extensive, and oftentimes more rapid, erosion (Bird, 1996).

Sea level rise will also likely submerge coastal areas, especially those in low-elevation coastal zones (McGranahan et al., 2007) or alongside riverbanks (Yasuhara et al., 2011). Coastal zones have historically attracted large human populations and their associated activities because of easy access to water transport and fishing grounds, their esthetic values, and the diverse ecosystem services that they provide (Luijendijk et al., 2018). Several studies have shown that the population in low-elevation coastal zones (defined as coastal areas < $10 \mathrm{~m}$ above sea level, a.s.l.) will likely increase from 640-700 million people in 2000 to over one billion in 2050 (Merkens et al., 2016). Hinkel et al. (2014) provided estimates showing that with sea levels set to rise by $25-123 \mathrm{~cm}$ through 2100 , as much as $0.2-4.6 \%$ of the global human population would experience flooding annually, with associated annual damages amounting to $0.3-9.3 \%$ of the Gross Domestic Product (GDP).

Indonesia is an archipelagic country with many small islands that are very vulnerable to sea level rise (Ministry of National Development and Planning, 2014). Sea level in Indonesian waters is projected to rise by $80.0 \pm 5.0 \mathrm{~cm}$ by 2100 (Indonesia Climate Change Sectoral Roadmap - ICCSR Scientific, 2010). This rise is expected to influence coastal areas of Indonesia in at least two ways: (a) an increase in the inundation area of coastal zones as the coastlines move, and (b) an areal increase in the zone affected by saltwater intrusions via river mouths and ground water (Ministry of National Development and Planning, 2014). Moreover, coastal areas in Indonesia have experienced severe erosion; 29,261 ha of the coastal zone has been eroded over 15 years (Siry, 2018). According to Climate Central (2019), coastal flooding triggered by sea level rise will affect around 23 million people living in the coastal zones of Indonesia by 2050 , with land losses worth US\$151 million globally. The Indonesian Government has repeatedly attempted to protect the coastal zone from the danger of erosion and flooding (Siry, 2018). In 2017, the government built $15 \mathrm{~km}$ of coastal protection structures using various procedures, such as the hard-engineering application of concrete, hybrid engineering using both hard structures and mangroves, and soft engineering using mangroves (Ministry of Marine Affairs and Fisheries, 2017). However, these efforts are not adequate given that the coastal areas affected by erosion are increasing in extent by about 420 km/year (Siry, 2018). Adaptation or adjustment that can be done to respond the impact of climate change-induced coastal disaster generally can be divided into four options: defense, accommodate, managed retreat and sacrifice (Williams et al., 2018). Defense differs from adaptation (accommodate) in the sense that adaptation refers to passive steps taken by humans in response to the approaching sea, while protection refers to an aggressive collection of policies aimed at preventing the sea from encroaching on land (McGuire, 2013). Defense focuses on preserving vulnerable areas, especially population centers, economic activities and natural resources using hard structures and/or soft protection measures (RangelBuitrago et al., 2018) such as seawall, bulkhead, groynes etc. (Bush et al., 1999) and soft structures including the use of mangroves as green belts, bamboo fences, sand dunes, and ecosystem-based coastal erosion management (Gracia et al., 2018). Its focus on the strategic displacement of human dwellings and villages from the coastal region as the sea moves landward distinguishes retreat from remaining in the coastal area (Nicholls, 2002). Another response to climate change impact in the coastal area is sacrifice, which means no active intervention to prevent or managed the impact and letting the nature to takes its courses (Williams et al., 2018). Techniques, expertise, facilities, and institutional resources must all be included in management strategies to reduce or eliminate coastal erosion-related impacts. Sometimes coastal protection strategies have been poorly planned and hastily constructed to reduce the impact of the erosion process, resulting in a coastal protection structure that is not fit for purpose (Rangel-Buitrago et al., 2018).

Conservation practitioners frequently face the fact that the cost of maintaining global biodiversity far exceeds available financial and human resources 
(Mace \& Possingham, 2006). In fact, the Government had to relocate some communities where the villages are heavily eroded such as Demak and Pekalongan, in Central Java Province (Asiyah et al., 2015), which was involved substantial funding (Jolliffe, 2016). Therefore, it is important to determine the appropriate sequence of intensive maintenance procedures for maximum benefit. This is an urgent task to protect the coast of Indonesia, which is surrounded by the sea. Spatial prioritization of conservation action has been particularly valuable for conservation planning (Wilson et al., 2009), it has been applied in a lot of studies on conservation (Moilanen et al., 2011; Lehtomäki \& Moilanen, 2013; Mendoza-Ponce et al., 2020). Prioritization methods can be divided into two main categories: scoring-based and complementarity-based approaches (Ferrier \& Wintle, 2009). In the approach based on scoring, for example, Singh et al. (2021) scored lakes based on four characteristics such as ecological lake characteristics, lake catchment characteristics, threat to the lake ecosystem, conservation and management policy. The complementarity approach (Leathwick et al., 2010; Kullberg et al., 2015; Monroy-Gamboa et al., 2019) chooses areas of complementary richness areas that in combination have the highest species richness. Marxan as complementarity approach have been used for conservation plans (Ban et al., 2013; Pasnin et al., 2016), such as design and establishment of conservation areas (Henriques et al., 2017). Several marine spatial planning tools including visual gradient overlay, categorical classification, Marxan as the target-based site optimization algorithm, and zonation conservation priority ranking were compared, Marxan proven to show better result (Allnutt et al., 2011).

The purpose of this study was to identify priority areas (administrative units below the provincial level) for coastal protection against sea level rise on Java Island, Indonesia, using the Marxan model as the complementarity approach. By detecting priority areas for protection, the Governments and NGOs will be able to invest funds and human resources efficiently and effectively.

\section{METHODOLOGY}

\section{Study Area}

The study area was on Java Island, Indonesia $\left(5^{\circ} 52^{\prime} \mathrm{S}-8^{\circ} 52^{\prime} \mathrm{S}, 105^{\circ} 7^{\prime} \mathrm{E}-114^{\circ} 37^{\prime} \mathrm{E}\right)$ (Figure 1). The terrestrial landscape of Java Island occupies about $150,000 \mathrm{~km}^{2}$ (Ministry of Public Works and Housing, 2017). The area is divided into six provinces: Banten, Special Capital Region of Jakarta, West Java (Jawa

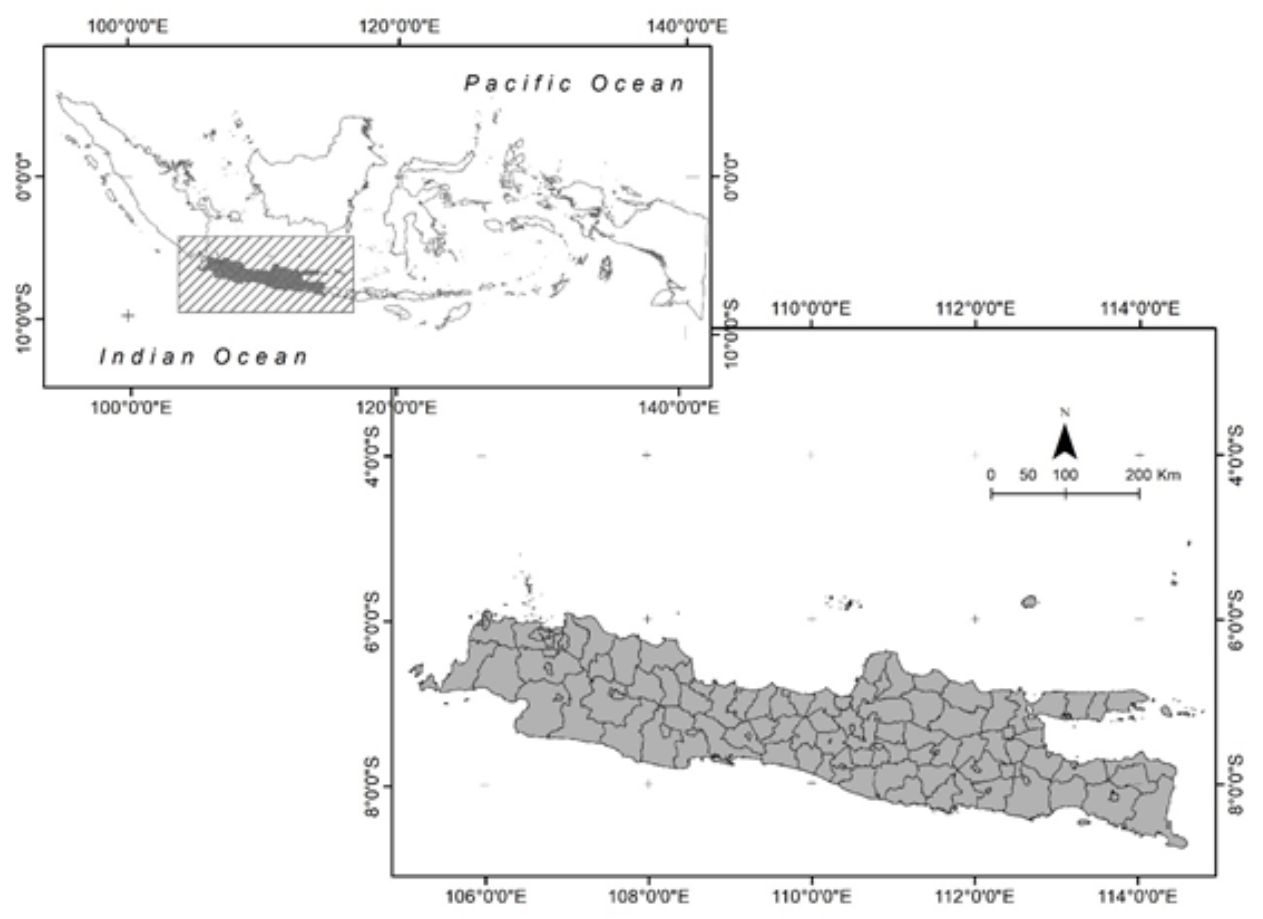

Figure 1. The island of Java with the Indian Ocean to the south and the Java Sea to the north. Java is divided into four administrative provinces (West Java, Central Java, East Java, and Banten), and two special regions (Jakarta and Yogyakarta). With a combined population of 145 million in the 2015 census, Java is the most populous island in the world; it is home to $57 \%$ of Indonesia's population. Regency boundaries on Java bounded were shown by thin lines. The coastline of the island is bounded by a thick line. Regencies were the units of analysis. 
Barat), Central Java (Jawa Tengah), Special Region of Yogyakarta, and East Java (Jawa Timur). Java Island is bordered by the Java Sea to the north, by the Indian Ocean to the south, by the Sunda Strait to the west, and the Bali and Madura Straits to the east. The average temperature on Java Island is in the range $22-29^{\circ} \mathrm{C}$; the average humidity is about $75 \%$ (climatedata.org, 2019). The coastal area of East Java, however, can be warmer, reaching about $35^{\circ} \mathrm{C}$ during the dry season in October (Statistics of East Java Province, 2018). The average annual rainfall is 2100 $\mathrm{mm}$ (Climate-data.org, 2019), with the highest precipitation falling on the Parahyangan highland (4000 mm; Statistics of West Java Province, 2018), and the lowest falling on the north coast of East Java (900 mm; Statistics of East Java Province, 2018).

The ocean waves off Java Island track seasonal patterns that are influenced by wind speed, wind period, and wind fetch, which is dependent on the coastal topographic configuration. The coastal areas of Gresik and Tuban in East Java have been categorized as semi-closed waters because they are connected directly to the coastal area of Borneo Island and Madura Island (Fisheries Agency of East Java, 2016). The Indramayu region has the largest waves that can reach heights $>1.7 \mathrm{~m}$; the smallest waves reach heights $<0.3 \mathrm{~m}$. The south coast of Java Island has largest wave heights of $2-5 \mathrm{~m}$ in offshore waters (Environmental Agency of West Java, 2008).

\section{Data Collection}

Ground surface attributes as input data for Marxan were mangrove areas, low-elevation areas, areas of increasing annual precipitation, fishpond areas, and watershed settlements. The mangrove, fishpond, and settlement area data were extracted from the Global Forest Watch Data website (http://data. globalforestwatch.org/), which uses land cover and land use data released by the Ministry of Environment and Forestry of Indonesia. The primary and secondary mangrove forest fields were extracted as designated mangrove areas. A 1-km buffer zone was created along the outlines of coasts and rivers; settlement areas were extracted and designated as watershed settlements. Low-elevation areas were calculated using the digital elevation model (spatial resolution of $30 \mathrm{~m}$ ) obtained from the Aster GDEM website (https://ssl. jspacesystems.or.jp/); areas that were $<10 \mathrm{~m}$ a.s.I. were isolated. Areas with potential annual increases in precipitation were identified using current and future annual precipitation estimates obtained from the WorldClim website (https://www.worldclim.org/). Current annual precipitation was obtained from interpolations in observed data that were representative of the period 1960-1990. The future annual precipitation was obtained from estimations made under the RCP8.5 scenario in 2070. The differences between current and future precipitations were calculated, and areas with more than $100 \mathrm{~mm}$ difference were categorized as those with potential increases in rainfall.

Figure 2 (a) shows the distribution of mangrove forests (primary and secondary) on Java. The total mangrove area on the island was $27,344.82$ ha. Of 117 areas, 22 had mangals. The largest coverage occurred in Sumenep Regency, East Java (11,409.02 ha), followed in rank order by Cilacap Regency $(7,409.55$ ha) in the southern part of Central Java. Lebak Regency in Banten Province had the smallest mangrove cover ( $3.43 \mathrm{ha}$ ). Figure 2 (b) shows the distribution of coastal and riverside settlements on Java. These settlements occupied 558,646.38 ha. Tangerang Regency in Banten had the largest coastal and riverside settlement area $(13,201.03 \mathrm{ha})$. The smallest settlement area occurred in Kepulauan Seribu Regency (31.35 ha). Of 117 areas, three had no coastal or riverside settlements: Cimahi City in West Java, Salatiga City in Central Java, and Blitar Regency in East Java. These three areas did not have coastlines or river channels. Figure 2 (c) shows the distribution of the low-elevation areas (<10 $\mathrm{m}$ a.s.I.), which occurred mostly in northern Java. The north coast of Java is low and flat, in contrast to the south coast, which is dominated by cliffs (Environmental Agency of West Java, 2008). The total low-elevation area occupied 1,144,830.93 ha. The largest lowelevation area occurred in Karawang Regency, West Java $(89,080.48$ ha). Jombang Regency in East Java had few low-elevation areas (7.74 ha), and 39 areas had no low-elevation areas. Figure 2 (d) shows the distribution of fishpond coverage on Java. The ponds occupied 189,377.27 ha, with most located in the northern part of West Java, where they occupied $76,852.74$ ha.

Indramayu Regency had largest fishpond coverage among areas $(27,265.36$ ha). Lebak Regency in Banten had the smallest fishpond coverage (2.19 ha). Only 48 of 117 areas had fishponds. Figure 2 (e) shows the distribution of areas in which the annual precipitation was projected to increase above current levels. The total area with projected precipitation increases of $>100 \mathrm{~mm}$ by 2070 covered $5,102,288.51$ ha, with the greatest concentrations in central to western Java. Sukabumi Regency in West Java and Purwokerto Regency in Central Java had the largest $(413,463.27 \mathrm{ha})$ and smallest (676.10 ha) areas with projected rainfall increases, respectively.

\section{Identification of Priority Areas for Coastal Protection Using Marxan}

We used Marxan software to identify priority areas for coastal protection. The model uses systematic planning to select prioritized areas for coastal protection (Mills et al., 2016). Marxan selects planning units for protection at a minimum total cost, while allowing for 


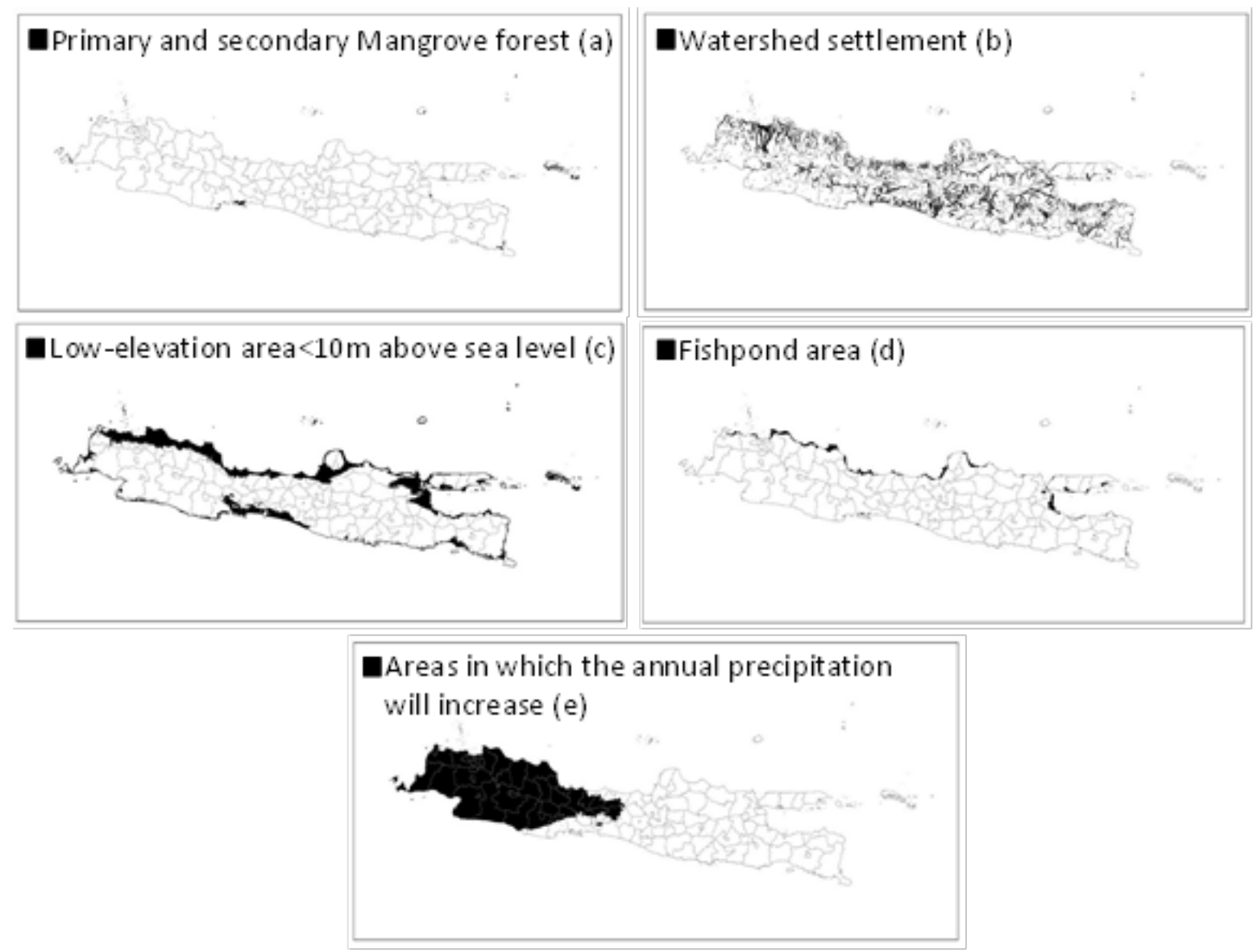

Figure 2. Attributes of land surface. Mangrove forest (primary and secondary) distribution on Java (obtained from Global Forest Watch; Land Cover Indonesia in 2017, (a)). Watershed settlement. Settlement area data were obtained from Global Forest Watch (Settlement area from Land Cover Indonesia in 2017). A 1-km buffer zone was created back from the line of coasts and rivers obtained from the DIVA-GIS Inland water database. Settlement areas were extracted and designated as watershed settlements (b). Low-elevation areas $<10 \mathrm{~m}$ above sea level calculated from ASTER GDEM data (c). Fishpond area obtained from Global Forest Watch data (Fishpond from Land Cover Indonesia in 2017, (d)). Areas in which the annual precipitation in 2070 is expected to exceed current levels (e). The 2070 projection was provided by the MIROC-ESM model under scenario RCP8.5 (WorldClim).

more or less emphasis on the spatial clustering of the selected planning units (Ball et al., 2009). Marxan estimations are controlled mainly by cost, target features, boundary, and status given for each ground surface attribute, which are incorporated in the following formula (Göke et al., 2018):

$\sum_{N_{0} s} \operatorname{cost}+\left(B L M * \sum_{v_{0 s}}\right.$ Boundary length $)+\sum_{\text {Tega fentuns }}$ Penalty $\left.* F P F\right)$

Here, PUs are the planning units that are potential parcels of land or sea to be included in the reserve or conservation network in a planning region (Game \& Grantham, 2008). Cost is the cost of including the sets of planning units into the configuration or conservation network (Morrell et al., 2015). Target Features is the object for conservation, and the target amount of each conservation feature is included in the solutions (Game \& Grantham, 2008). The Boundary length of the reserve system is a means of quantifying the connectivity of a configuration of planning units (Morrell et al., 2015). BLM is boundary length modifier which is a variable used to determine how much emphasis is placed on minimizing the overall reserve system boundary length (Game \& Grantham, 2008). Penalty is the difference between the target set and the selected amount. FPF is the feature penalty factor, which is the penalty factor applied for not reaching the target for the feature (Göke et al., 2018). The Marxan algorithm uses iterations to optimize this equation. In our study, Marxan ran 100 different iterations to find the best solution. The best solution file lists the reserve or conservation network with the lowest score across all good reserve networks generated (Ball et al., 2009). 
A scenario is usually defined as a particular simulation circumstance based on assumptions about extrinsic drivers, parameters, and the structure of the model (Peterson et al., 2003). In this study, we developed three scenarios based on the main target of conservation (Table 1). In the strategy of selection and concentration, scenario 1 focused on the mangrove ecosystem. Mangrove areas in Java have been converted into brackish water fish and shrimp ponds on a large scale. The method of intensive shrimp farming introduced in 1970 coincided with the strong market demand and prices for shrimp at the time, resulting in a significant transformation of mangroves (Wouthuyzen et al., 2014). The loss due to this conversion is estimated at 1.6 million ha. Conversion of mangrove areas in 1980s was 155,081 ha, mostly taking place in Java, Sumatra and Sulawesi and increased to 285,500 ha in the 1990 s (Nusantara et al., 2015). On the other hand, these conversion of mangrove areas has weakened or even eliminate the ability of mangrove areas to provide ecosystem services in terms of coastal protection, water purification, as well as carbon sequestration (Van Oudenhoven, 2015). We identified those areas where more effort and funding can be allocated for conserving and maintaining mangrove ecosystems by selecting areas based on the distribution of mangals and low-elevation zones. Because the mangrove ecosystem is important for reducing coastal erosion (Máñez et al., 2014) and the area occupied by mangals is decreasing (Siry, 2018), we need to conserve existing mangrove zones. Combined with other structures, mangroves could also be planted in low-elevation areas to protect coastal zones (Tonneijck et al., 2015). Under scenario 1, the goal was to protect $80 \%$ of both existing mangals and low-elevation areas with the potential for mangrove planting. The aim was also to protect $50 \%$ of the fishpond area because fish farmers sometimes plant mangroves to supply nutrients to the ponds and maintain the water quality.

Aquaculture is one of the main industries on Java; in 2017 , it generated $8-9 \%$ of the GDP, and it has become one of the main livelihoods. About 150,000 households engage in this region (Ministry of Marine Affairs and Fisheries, 2018; Statistics of West Java Province, 2018). The investment in fisheries industries in Java, especially in Central Java, East Java, and West Java, is very high, representing about $34 \%$ of total investment in 2017, i.e., about 1.6 trillion IDR (Siry, 2018). Scenario 2 focused on fish farmers' livelihoods. The aquaculture area in Java including fish and shrimp ponds is under immediate threat, which is coastal erosion. For example, in Subang, a regency in West Java Province, $97.14 \%$ of fishponds have disappeared due to coastal erosion and flooding from 1990-2018 (Kalther \& Itaya, 2020). Severe coastal erosion was also found in several neighboring regions such as

Table 1.

Three scenarios developed for Marxan analysis based on ecological, economic, and disaster components impacted by sea level rise. Coastline length, mangrove coverage, low-elevation area, fishpond area, human settlement area, and the area with potential annual rainfall increases were selected as environmental factors.

\begin{tabular}{|c|c|c|c|}
\hline & Scenario 1 & Scenario 2 & Scenario 3 \\
\hline Scenario & $\begin{array}{l}\text { Which areas should be allocated } \\
\text { more effort and funding for } \\
\text { conserving and maintaining the } \\
\text { mangal ecosystem? }\end{array}$ & $\begin{array}{l}\text { Which areas should be allocated } \\
\text { more effort and funding } \\
\text { to maintain fish farmers' } \\
\text { livelihoods? }\end{array}$ & $\begin{array}{l}\text { Which areas should be allocated } \\
\text { more effort and funding for } \\
\text { protection from flooding? }\end{array}$ \\
\hline Planning unit & Regencies in Java & Regencies in Java & Regencies in Java \\
\hline Status & $\begin{array}{l}\text { Length of coastline and } \\
\text { river channels }=0, \text { status }=3 . \\
\text { Lengths of coastline and river } \\
\text { channels }>0, \text { status }=0\end{array}$ & $\begin{array}{l}\text { Length of coastline }=0, \text { status }=3 \\
\text { Lengths of coastline and river } \\
\text { channels }>0, \text { status }=0\end{array}$ & $\begin{array}{l}\text { Length of coastline and river } \\
\text { channels }=0, \text { status }=3 \\
\text { Length of coastline and river } \\
\text { channels }>0, \text { status }=0\end{array}$ \\
\hline Cost & $\begin{array}{l}\text { Lengths of coastline and } \\
\text { river channels }\end{array}$ & Length of coastline & $\begin{array}{l}\text { Lengths of coastline and } \\
\text { river channels }\end{array}$ \\
\hline Boundary length & 0 & 0 & 0 \\
\hline $\begin{array}{l}\text { Target and } \\
\text { proportion }\end{array}$ & $\begin{array}{l}\text { Area of mangal } 80 \% \text {. } \\
\text { Area of low-elevation zone } 80 \% \text {. } \\
\text { Increase in annual precipitation } \\
10 \% \text {. Area of fishponds } 50 \% \text {. } \\
\text { Area of watershed settlements } \\
10 \% \text {. }\end{array}$ & $\begin{array}{l}\text { Area of mangal } 10 \% \text {. } \\
\text { Area of low-elevation zone } 50 \% \text {. } \\
\text { Increase in annual precipitation } \\
10 \% \text {. Area of fishponds } 80 \% \text {. } \\
\text { Area of watershed settlements } \\
50 \% \text {. }\end{array}$ & $\begin{array}{l}\text { Area of mangal } 50 \% \text {. } \\
\text { Area of low-elevation zone } 80 \% \text {. } \\
\text { Increase in annual precipitation } \\
50 \% \text {. Are of fishponds } 10 \% \text {. } \\
\text { Area of watershed settlements } \\
80 \% \text {. }\end{array}$ \\
\hline
\end{tabular}


Karawang (Azhar, 2012), Semarang (Marfai, 2011), and Demak (Sasmito \& Suprayogi, 2017), which were mainly covered by aquaculture area according to the land use map. In addition, most people engaged in this industry, especially the small-scale fish farmers, are living under poverty (Natalia \& Alie, 2014). These facts offer a strong reason for protecting the aquaculture area. We identified those areas where more effort and funding can be allocated to maintain fish farmers' livelihoods by selecting areas according to the distribution of fishponds. The goal of this scenario was to protect $80 \%$ of fishponds. It also aimed to protect $50 \%$ of low-elevation areas and watershed settlements because they are target areas for fishing and daily livelihoods of fish farmers.

Scenario 3 focused on residential area. We identified those areas where more effort and funding can be allocated for flood protection by selecting areas based on the distribution of low-elevation zones and watershed settlements. With a population of over 141 million on Java Island, or 145 million including the inhabitants of the surrounding islands, Java supports $56.7 \%$ of the Indonesian population and is the world's most populous island (BPS - Statistics Indonesia, 2013). Recent reports show that about $65 \%$ of Java's population inhabits the coastal zone. Coastal flooding is a serious threat to coastal areas around the world. It is responsible for billions of dollars worth of damage to property and infrastructure, and it threatens the lives of millions of people (Dasgupta et al., 2009). The coastal zones of Jakarta and Semarang in Central Java already have acute coastal flooding problems that create immense difficulties for many people in Indonesia (Miladan, 2009; Ward et al., 2011). Several coastal cities in such as Semarang (Ramadhany et al., 2012) and Demak (Sasmito \& Suprayogi, 2017) are regularly flooded during high tide, which affects the social and economic activities of coastal communities as well as the sustainability of coastal ecosystem (Marfai, 2011). Moreover, most coastal communities in these areas live below the poverty line, making them highly vulnerable to coastal flooding and other forms of coastal disasters (Miladan, 2009; Ramadhany et al., 2012). Under scenario 3, the goal was to protect $80 \%$ of low-elevation areas and watershed settlements where flooding is a possibility. Another goal was to protect $50 \%$ of mangal coverage and areas where precipitation is expected to increase in the future because these are flood-sensitive areas.

The planning units in this study were generated based on regencies in Java obtained from the DIVAGIS (https://www.diva-gis.org/gdata) database. Regencies belonging to West Java, Central Java, East Java, the Special Region of Yogyakarta, Banten, and the Special Capital Region of Jakarta were separated from the original data. We included 117 planning units
(PUs) in our analysis and used status to lock planning units into or out of the reserve system. The total coastline length of Java is $6223.36 \mathrm{~km}$. Of 117 areas on the island, 60 have coastlines. Sumenep Regency in East Java has the longest coastline $(1055.27 \mathrm{~km})$. Cirebon City in West Java has the shortest coastline (3.72 km).

A PU with status 0 indicated that it was not guaranteed inclusion in the initial or seed reserve; however, the possibility still existed. The chance of being included in the initial reserve was the starting proportion from the parameter input file. A PU with status 3 indicated that it was fixed outside of the reserve. It was not included in the initial reserve and could not be added. We defined status based on the lengths of coastlines and river channels. The lengths of coastlines and river channels were used as the cost value for each PU in scenarios 1 and 3 , whereas we used only the length of coastline as the cost value for scenario 2 . The outlines of coasts and rivers were obtained from the DIVA-GIS database. BLM was set to 0 , meaning the algorithm ignored boundary length, based on the assumption that the large size of individual planning units is effective for coastal protection and that compactness is not critical for reserve design given our research question (Drever et al., 2019). The FPF was set to 1 , as we do not prioritize one conservation features over another.

Under our scenarios, $80 \%$ of the total area of the features in highly important targets would be protected. For fairly important targets, $50 \%$ of the total area of the features would be protected. For less important targets, only $10 \%$ of the total area of the features would be protected.

\section{RESULTS AND DISCUSSION}

Climate change-induced sea level rise will likely increase the severity of ongoing coastal disasters in Indonesia. These disasters include coastal erosion, coastal flooding, and loss of important ecosystems and activities in the coastal zone. The selection and concentration approach should be applied to minimize the costs of conservation when budgets are limited. Prioritizing is then effective in terms of cost effectiveness. Although conservation priorities and management actions in marine systems have been mapped using scoring-based and complementaritybased approaches (Lourie \& Vincent, 2004; Sala et al., 2002; Ball et al., 2009; Leathwick et al., 2008), some reports have shown that Marxan as complementaritybased approach is more able than other methods in terms of accuracy (e.g. Allnutt et al., 2012). Marxan was applied to solve problems encountered in marine conservation network planning to protect diverse components of biodiversity (Ball et al., 2009). For 
instance, Mills et al. (2016) used Marxan to identify appropriate methods for adapting to sea level rise. Henriques et al. (2017) used Marxan to select the best areas for aquaculture management. The model uses systematic planning to select prioritized areas for coastal protection. Therefore, using the Marxan we aimed to identify priority areas for coastal protection against sea level rise around Java, Indonesia.

Three scenarios were developed based on ecological, economic, and disaster elements that were exacerbated by sea level rise. A scenario is defined as a particular simulation circumstance based on assumptions about extrinsic drivers, parameters, and the structure of the model. Coastline length, mangrove coverage, low-elevation area, fishpond area, human settlement area, and the area of zones with the potential for annual rainfall increases acquired from DIVA-GIS and WorldClim were set as environmental factors.

Marxan software identified the regencies in which more effort and funding can be provided for conserving and maintaining the mangrove ecosystem (Figure 3 (a)). Of the 117 regencies, $22(18.8 \%)$ were selected as priority areas. Most of the selected regencies were located in northern Java, except for Cilacap Regency located in southern Java. Sumenep Regency and Cilacap Regency had the largest and second largest mangrove forests. Scenario 1 focused on mangrove ecosystems. Multiple studies have shown that mangals are important natural barriers in coastal areas (Danielsen et al., 2005; Gedan et al., 2011; Máñez et al., 2014; Spalding et al., 2014). Mangrove roots stabilize shoreline sediments to protect against erosion, and the aboveground organs of the trees function to dampen the forces of wind and waves (Danielsen et al., 2005). Mangroves have economic benefits for coastal communities, directly through the provision of timber and fuel, and indirectly by providing habitat and nursery areas for fish and other animals (Máñez et al., 2014). Unfortunately, the mangal cover in Indonesia has been declining steadily, particularly on Java. Between 2010 and 2015, the annual cover loss was about 41.055 ha (Siry, 2018). The main driver behind mangrove loss is conversion to fish or shrimp ponds (Novianty et al., 2012). The extensive coastlines and long river channels in the 22 selected areas will require expanded effort and funding to protect the mangrove forests in balance with the fishery sector. The mangrove forest in the selected areas occupied $19,728.27$ ha, representing $72 \%$ of the total mangrove area on Java. The extensive coastlines and long river channels in the 22 selected areas will require expanded effort and funding to protect the mangrove forests in balance with the fishery sector. A mechanism called "Tambak Tumpangsari" or silvofishery may be an option that can meet both needs (Kiswanto, 2015). It is a unique aquaculture method that allows both aquatic animals and mangrove trees to be reared in the same pond (Takashima, 2000). In terms of protection strategies for sustaining the mangrove forest, various activities such as mangrove restoration or replanting activities (Setyawan et al., 2002) and protection of

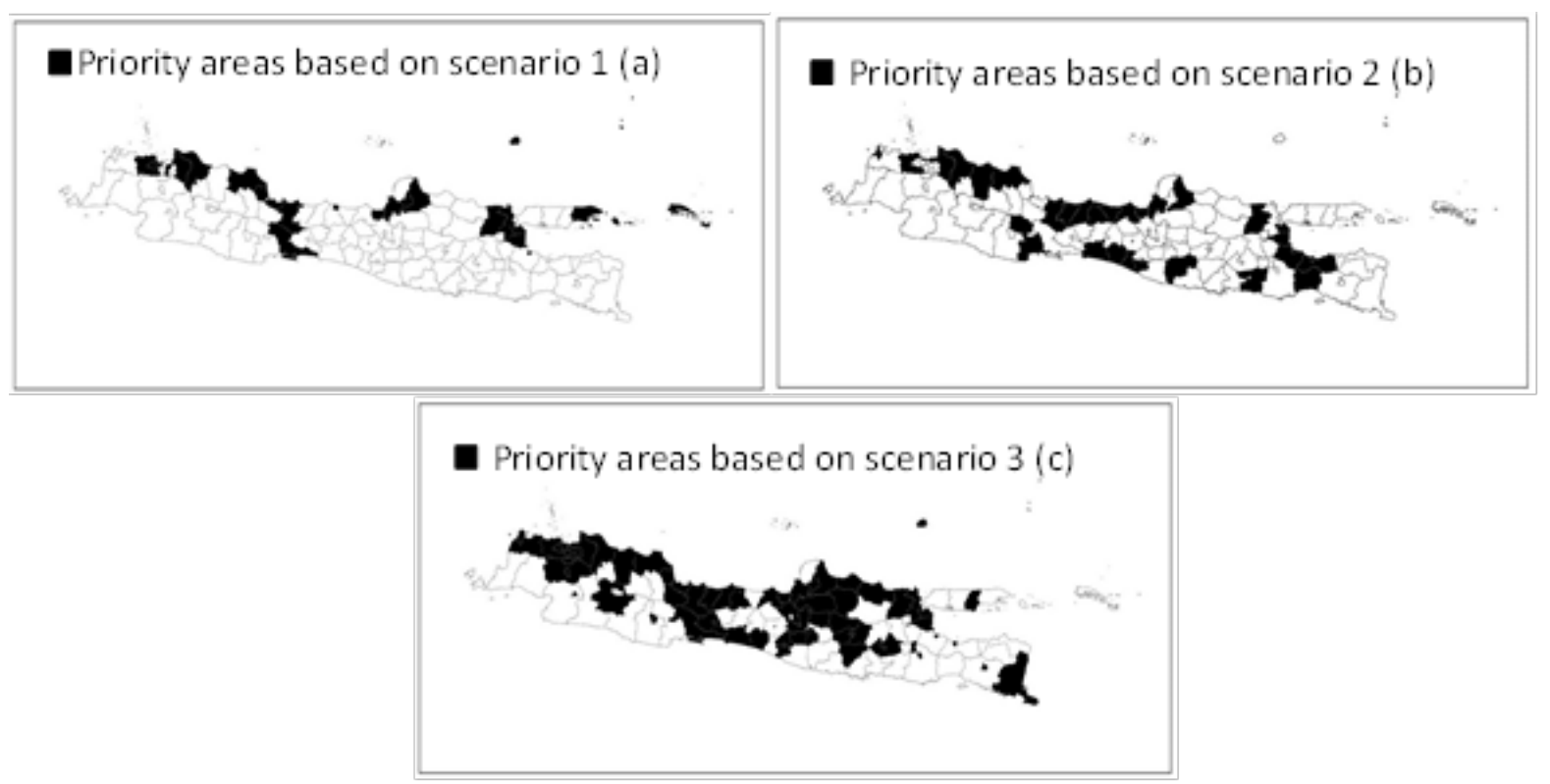

Figure 3. Areas (identified by Marxan software) where effort and funding supports will be effective for the best conservation and maintenance of the mangrove ecosystem (black area in (a)). Areas to which effort and funding will be effective to direct to best maintain fish farmers' livelihoods (black area in (b)). areas to which effort and funding will be effective to direct to provide the best protection against flooding (black area in (c)). 
mangrove seedlings with bamboo fences have been implemented (Nusantara et al., 2015). In 2017, the Indonesian government planted mangroves in at least 5 kilometers of the critical coastal area in Java as a coastal protection measure (Ministry of Marine Affairs and Fisheries, 2017). The outcome of scenario 1 can provide insight on where next coastal protection can be implemented focusing on the mangrove ecosystem.

Figure 3 (b) shows the regencies selected under scenario 2 to which increased effort and funding can be directed to maintain fish farmers' livelihoods. Among the 117 regencies, 34 (29.1\%) identified for inclusion in the priority area were concentrated mostly in northern Java. Only eight were located in southern Java. Except for Cirebon Regency, all regencies in northern West Java, where most fishponds were located, were selected for inclusion in the priority area. Scenario 2 focused on fish farmers' livelihoods. The fishery sector on Java is very important economically. In West Java, the fishery sector generated 8-9\% of the GDP in 2017 (Statistics of West Java Province, 2018). In East Java, around 311,000 tons of fishery products were produced by brackish water aquaculture (Statistics of East Java Province, 2018). Therefore, it was unsurprising that the output of Marxan analysis was focused strongly in the northern part of West Java and East Java under scenario 2. If fishponds and low-elevation areas become inundated due to sea level rise, it would cause great damage to the fishery industry. However, the extensive coastlines would certainly complicate any programs aiming to increase effort and funding. Additional effort and funding to maintain fish farmers' livelihoods might be better to allocate to the 34 areas selected. The fishpond area in the areas selected under this scenario occupied $151,671.08$ ha, or about $80 \%$ of the total fishpond area on Java. Under the status established for this scenario, Marxan needs to identify more than half of all areas available for selection in order to satisfy the conservation target. It is possibly due to the distribution of fishpond area, which mostly scattered in the northern part of Java. In contrast, for low-lying areas and watershed settlements, the target achievement is $65 \%$ and $28 \%$ respectively. The target for the low-lying areas is met by Marxan (the target is $50 \%$ ), while the target for the coastal and watershed settlements is not met (the target is $50 \%$ ) This was likely influenced by the distribution of coastal settlements within the planning units where fishponds dominate. Coastal and watershed settlements were extracted from settlements within a 1-km buffer area from the shoreline and rivers. On the other hand, in the planning units where fishponds predominate, the $1-\mathrm{km}$ buffer zones were mostly covered by fishponds and only few settlements were found. Thus, when Marxan attempts to meet the targets for fishpond area, it sacrifices the watershed settlement target.
Figure 3 (c) shows the regencies to which effort and funding can be directed based on scenario 3 to increase protection against flooding. Under this scenario, 73 of 117 regencies $(62.4 \%)$ were selected for inclusion in the priority areas. Scenario 3 focused on protecting people from flooding. Coastal flooding has occurred frequently in many large Indonesian coastal cities (Marfai \& King, 2007). Some areas, such as Karawang (Azhar, 2012), Semarang (Marfai, 2011), and Demak (Sasmito \& Suprayogi, 2017), have already experienced severe coastal erosion. Semarang (Ramadhany et al., 2012) and Demak (Sasmito \& Suprayogi, 2017) also regularly experience coastal floods. The extensive coastlines and long river channels increase the extent of area sensitive to flooding, thereby increasing the demands on effort and funding programs. The extra effort and funding to increase protection from flooding might be better to allocate to the 73 areas selected. The selected areas occupy $403,317.50$ ha, or $72 \%$ of total watershed settlement on Java. The number of selected areas in scenario 3 is much higher compared to the other scenarios. This is probably due to the target set for this scenario rather high. However, in this scenario, all the conservation targets were met by Marxan except for the mangrove areas, which represent only $41 \%$ (the target is $50 \%$ ). It is also interesting to note that although the target for fishpond area is only $10 \%$, the percentage of fishpond cover within the selected areas is $89 \%$. This scenario focuses on flood-prone areas; therefore, the primary target is the low-elevation area. When Marxan attempts to meet the low elevation area's target, the fishpond area's target will also be achieved since most of the low elevation areas are covered by or used as fishpond.

There were 60 areas facing the coast among 117 areas. For those protection, it would be fairly costly. We were able to narrow that number down from $12.3 \%$ to $62.4 \%$ from 117 areas using our method. This might become very cost effective. The most prioritized areas were located in the northern region of Java. These areas can be a focus of preferential effort and funding for conservation. The results of this study will help to make the protection strategy based on not only the magnitude of damage but also the total perspective using public data that is relatively easy to obtain. To ensure the sustainability of coastal ecosystems and all activities within them, diverse procedures have been implemented by both by the Indonesian Government and the local communities (Azhar, 2012; Ministry of Marine Affairs and Fisheries, 2017). In 2017, the government built about $15 \mathrm{~km}$ of coastal protection using hard, soft, and hybrid structures (Ministry of Marine Affairs and Fisheries, 2017). Based on the trend in budget allocation for coastal protection in the past, the limited funding allocated by the government will be sufficient to protect only $10-20 \mathrm{~km}$ of the coastal zone annually. By providing effectiveness insights, our study 
supports decision making by planners choosing sites for the construction of coastal protection structures or coastal forest rehabilitation programs. The combination of manufactured structures with natural mangal barriers is one of the best available options to minimize the cost of coastal protection (Tonneijck et al., 2015).

\section{CONCLUSION}

Using the Marxan model, we identified areas in Indonesia that can be the focus of increased effort and funding to deal with the rising sea level crisis. The selection of concentrated areas targeted for conservation is important because the budgets available for such programs are limited. With focuses on ecological, economic, and disaster elements, scenarios 1,2 , and 3 selected 22,34 , and 73 areas, respectively, among 117 on Java. We were able to narrow that number down from $12.3 \%$ to $62.4 \%$ from 117 areas using our method using public data that is relatively easy to obtain. By providing effectiveness insights, our study supports decision making by planners choosing sites for the construction of coastal protection structures or coastal forest rehabilitation programs. Thus, our findings can support the fisheries sector in the study area as the main livelihood of coastal communities and the areas' main source of GDP as well as their settlement areas by considering their sustainability in the selection of priority areas for coastal protection as a social and economic contribution, and in terms of environmental contribution, it supports the protection of important coastal habitat, mangrove areas, which is not only essential as natural barriers of coastal areas from waves but also provide an immense amount of ecosystem services to coastal communities.

\section{ACKOWLEDGEMENTS}

We would like to express our great appreciation to Prof. Ishikawa, who provided helpful comments and suggestions. We would also like to thank the Japanese Ministry of Education, Culture, Sports, Science and Technology for a scholarship that made it possible to complete this study.

\section{REFFERENCE}

Allnutt, T.F., McClanahan, T.R., Andréfouët, S., Baker, M., Lagabrielle, E., McClennen, C., Rakotomanjaka, A.J.M., Tianarisoa, T.F., Watson, R., \& Kremen C (2012). Comparison of marine spatial planning methods in Madagascar demonstrates value of alternative approaches. PLoS One, 7(2), e28969. doi: 10.1371/journal.pone.0028969.

Arkema, K.K., Guannel, G., Verutes, G., Wood, S.A., Guerry, A., Ruckelshaus, M., Kareiva, P., Lacayo, M., \& Silver, J.M. (2013). Coastal habitats shield people and property from sea-level rise and storms. Nat Clim Chang, 3(10), 913-918. doi: 10.1038/nclimate1944.

Asiyah, S., Rindarjono, M.G., \& Muryani, C. (2015, in Indonesian). Analysis of Settlement Changes and Characteristics of Slum Settlements Due to Abrasion and Inundation in the Coastal of Sayung District, Demak Regency 2003 - 2013. J GeoEco, 1, 83-100.

Azhar, R.M. (2012, in Indonesian). Physical vulnerability of the coastal zone on the north coastal of Karawang in West Java. Undergraduate Thesis, Universitas Padjadjaran.

Ball, I.R., Possingham, H.P., \& Watts, M.E. (2009). Marxan and relatives: software for spatial conservation prioritization. In: Moilanen, A., Wilson, K.A., \& Possingham, H.P. (eds) Spatial conservation prioritization. Quantitative methods \& computational tools. Oxford University Press, United Kingdom, pp 185-195.

Ban, N.C., Bodtker, K.M., Nicolson, D., Robb, C.K., Royle, K., \& Short, C. (2013). Setting the stage for marine spatial planning: Ecological and social data collation and analyses in Canada's Pacific waters. Mar Policy, 39, 11-20. doi: 10.1016/j. marpol.2012.10.017.

Bird, E.C.P. (1996). Coastal erosion and rising sealevel. In: Milliman JD, Haq (Eds.) BU (eds) SeaLevel Rise and Coastal Subsidence. Springer, Dordecht, The Netherlands, pp 87-103, doi: 10.1007/978-94-015-8719-8_5.

BPS-Statistics Indonesia (2013, in Indonesian and English). Indonesia population projection 2010 2035. Ministry of National Development and Planning, Jakarta, BPS-Statistics Indonesia, pp. 470.

Bush, D.M., Neal, W.J., Young, R.S., \& Pilkey, O.H. (1999). Utilization of geoindicators for rapid assessment of coastal-hazard risk and mitigation. Ocean Coast Manag, 42(8), 647-670. doi: 10.1016/S0964-5691(99)00027-7.

Climate-data.org (2019). Climate of Java. https:// en.climate-data.org/asia/indonesia/westjava-2408/. Accessed 15 Oct 2019.

Climate Central (2019). Flooded future: global vulnerability to sea level rise worse than previously understood. Climate Central, Jakarta, pp. 12

Danielsen, F., Sørensen, M.K., Olwig, M.F., Selvam, V., 
Parish, F., Burgess, N.D., Hiraishi, T., Karunagaran, V.M., Rasmussen, M.S., Hansen, L.B., Quarto, A., \& Suryadiputra, N. (2005). The Asian Tsunami: a protective role for coastal vegetation. Science, 310(5748) :643. doi: 10.1126/science.1118387.

Dasgupta, S., Laplante, B., Meisner, C., Wheeler, D., \& Yan, J. (2009). The impact of sea level rise on developing countries: a comparative analysis. Clim Change, 93, 379-388. doi: 10.1007/s10584008-9499-5.

Drever, C.R., Hutchison, C., Drever, M.C., Fortin, D., Johnson, C.A., \& Wiersma, Y.F. (2019). Conservation through co-occurrence: Woodland caribou as a focal species for boreal biodiversity. Biological Conservation, 232(5), 238-252.

Ferrier, S., \& Wintle, B.A. (2009). Quantitative approaches to spatial conservation prioritization: matching the solution to the need. In Spatial Conservation Prioritization (eds Moilanen, A., Wilson, K. A., \& Possingham, H. P.), pp. 1- 15. Oxford University Press, Oxford.

Environmental Agency of West Java. (2008, in Indonesian). Environmental status of West Java 2008. Environmental Agency of West Java, Bandung, http://dlh.jabarprov.go.id/index.php/ layanan/dokumen/kegiatan/slhd/tahun-2008. Accessed 15 Oct 2019.

Fisheries Agency of East Java. (2016, in Indonesian) Profile of coastal village in East Java Volume 1 (North Coast). Fisheries Agency of East Java, Surabaya pp. 89.

Game, E.T., \& Grantham, H.S. (2008). Marxan user manual. University of Queensland, St. Lucia, Queensland, Australia, and Pacific Marine Analysis and Research Association, Vancouver, British Columbia, Canada, pp. 135.

Gedan, K.B., Kirwan, M.L., Wolanski, E., Barbier, E.B., \& Silliman, B.R. (2011). The present and future role of coastal wetland vegetation in protecting shorelines: Answering recent challenges to the paradigm. Clim Change, 106, 7-29. doi: 10.1007/ s10584-010-0003-7.

Göke, C., Dahl. K, \& Mohn, C. (2018). Maritime spatial planning supported by systematic site selection: applying Marxan for offshore wind power in the Western Baltic Sea. PLoS One, 13:e0194362, doi: 10.1371/journal.pone.0194362.

Gracia, A., Rangel-Buitrago, N., Oakley, J.A., \& Williams, A.T. (2018). Use of ecosystems in coastal erosion management. Ocean Coast Manag, 156, 277289. doi: 10.1016/j.ocecoaman.2017.07.009.

Henriques, N.S., Monteiro, P., Bentes, L., Oliveira, F., Afonso, C.M.L., \& Gonçalves, J.M.S. (2017). Marxan as a zoning tool for development and economic purposed areas - Aquaculture Management Areas (AMAs). Ocean Coast Manag, 141, 90-97. doi: 10.1016/j. ocecoaman.2017.03.016.

Hinkel, J., Lincke, D., Vafeidis, A.T., Perrette, M., Nicholls, R.J., Tol, R.S.J., Marzeion, B., Fettweis, X., Ionescu, C., Levermann, A. (2014). Coastal flood damage and adaptation costs under 21st century sea-level rise. Proc Natl Acad Sci, 111, 3292-3297. doi: 10.1073/pnas.1222469111.

Indonesia Climate Change Sectoral Roadmap - ICCSR Scientific. (2010). Scientific Basis: Analysis and projection of sea level rise and extreme weather event. Ministry of National Development and Planning, Jakarta, pp. 89.

Jolliffe, J. (2016). Economic dimensions of relocation as an adaptation strategy to climate change: $A$ case study of the Narikoso Relocation Project, Fiji. Pacific Community, Suva, pp. 55.

Kalther, J, \& Itaya, A. (2020). Coastline changes and their effects on land use and cover in Subang, Indonesia. J Coast Conserv, 24(2). doi: 10.1007/ s11852-020-00736-w.

Kiswanto, H. (2015, in Indonesian). The Environmental Characteristics of Intercropping Pond in Subang, West Java as a Reference for The Mud Crabs Pond Aquaculture Development. Thesis, Bogor Agricultural University, pp. 20.

Kullberg, P., Toivonen, T., Pouzols, F.M., Lehtomäki, J., Di-Minin, E., \& Moilanen, A. (2015). Complementarity and area-efficiency in the prioritization of the global protected area network. PLOS ONE, 10(12), e0145231. doi: 10.1371/ journal.pone.0145231.

Leathwick, J., Moilanen, A., Francis, M., Elith, J., Taylor, P., Julian, K., Hastie, T., \& Duffy, C. (2008). Novel methods for the design and evaluation of marine protected areas in offshore waters. Conservation Letters, 1(2), 91-102. doi: 10.1111/j.1755263x.2008.00012.x.

Leathwick, J.R., Moilanen, A., Ferrier, S., \& Julian, K. (2010). Complementarity-based conservation prioritization using a community classification, and its application to riverine ecosystems. Biological 
Conservation, 143(4), 984-991. doi: 10.1016/j. biocon.2010.01.012.

Lehtomäki, J., \& Moilanen, A. (2013). Methods and workflow for spatial conservation prioritization using Zonation. Environ Model \& Softw, 47(September 2013), 128137. doi: 10.1016/j. envsoft.2013.05.001.

Lourie, S.A., \& Vincent, A.C.J. (2004). Using biogeography to help set priorities in marine conservation. Conservation Biology, 18(4), 10041020. doi: 10.1111/j.1523-1739.2004.00137.x.

Luijendijk, A., Hagenaars, G., Ranasinghe, R., Baart, F., Donchyts, G., \& Aarninkhof, S. (2018). The State of the World's Beaches. Sci Rep, 8, 1-11. doi: 10.1038/s41598-018-24630-6.

Mace, G.M., \& Possingham, H.P. (2006). Prioritizing choices in conservation. In: Macdonald, D., \& Service, K. (eds) Key Topics in Conservation Biology, 1st edn. Willy-Blackwell, New Jersey, pp 17-34.

Máñez, K.S., Krause, G., Ring, I., \& Glaser, M. (2014). The Gordian knot of mangrove conservation: Disentangling the role of scale, services and benefits. Glob Environ Chang, 28, 120-128. doi: 10.1016/j.gloenvcha.2014.06.008.

Marfai, M.A. (2011). The hazards of coastal erosion in Central Java, Indonesia: an overview. Malaysian. J Soc Sp, 7, 1-9.

Marfai, M.A., \& King, L. (2007). Monitoring land subsidence in Semarang, Indonesia. Environmental Geology, 53(3), 651-659. doi: 10.1007/s00254-007-0680-3.

McGranahan, G., Balk, D., \& Anderson, B. (2007). The rising tide: Assessing the risks of climate change and human settlements in low elevation coastal zones. Environment and Urbanization, 19(1), 1737. doi: 10.1177/0956247807076960.

McGuire, C.J. (2013). Adapting to Sea Level Rise in the coastal zone: Law and Policy Considerations, Taylor \& Francis Group, Boca Raton, FL, US pp. 222. doi: $10.4324 / 9781315097572$.

Mendoza-Ponce, A.V., Corona-Núñez, R.O., Kraxner, F., \& Estrada, F. (2020). Spatial prioritization for biodiversity conservation in a megadiverse country. Anthropocene. doi: 10.1016/j. ancene.2020.100267.

Merkens, J., Reimann, L., Hinkel, J., \& Vafeidis, A.T.
(2016). Gridded population projections for the coastal zone under the Shared Socioeconomic Pathways. Global and Planetary Change, 145, 57-66. doi: 10.1016/j.gloplacha.2016.08.009.

Miladan, N. (2009, in Indonesian) Study of climate change vulnerability of the Coastal Area of Semarang. Master Thesis, Dipenogoro University, pp. 16.

Mills, M., Leon, J.X., Saunders, M.I., Bell, J., Liu, Y., O'Mara, J., Lovelock, C.E., Mumby, P.J., Phinn, S., Possingham, H.P., Tulloch, V.J.D., Mutafoglu, K., Morrison, T., Callaghan, D.P., Baldock, T., Klein, C.J., \& Hoegh-Guldberg, O. (2016). Reconciling development and conservation under coastal squeeze from rising sea level. Conservation Letters, 9(5), 361-368. doi: 10.1111/conl.12213.

Ministry of Marine Affairs and Fisheries. (2017, in Indonesian). Annual Report of 2017. Ministry of Marine Affairs and Fisheries, Jakarta pp. 35.

Ministry of Marine Affairs and Fisheries. (2018, in Indonesian and English). Marine and Fisheries in Figures 2018. Ministry of Marine Affairs and Fisheries, Jakarta, http://sidatik.kkp.go.id/files/ src/023dfaa957829d846cfb59164b6c5774.pdf. Accessed 15 Oct 2019.

Ministry of National Development and Planning. (2014, in Indonesian). National action plan on climate change adaptation. Ministry of National Development and Planning, Jakarta, pp. 204.

Ministry of Public Works and Housing. (2017). Statistical Information Book 2017. Ministry of Public Works and Housing, Jakarta, pp. 113.

Moilanen, A., Leathwick, J.R., \& Quinn, J.M. (2011). Spatial prioritization of conservation management. Conservation Letters, 4(5), 383-393. doi: 10.1111/j.1755-263X.2011.00190.x.

Monroy-Gamboa, A.G., Briones-Salas, M.Á., Sarkar, S., \& Sánchez-Cordero, V. (2019). Terrestrial vertebrates as surrogates for selecting conservation areas in a biodiversity hotspot in Mexico. Conservation Science and Practice, 1(3), e12. doi: https://doi.org/10.1111/csp2.12.

Morrell, N., Schuster, R., \& Arcese, P. (2015). Marxan tutorial for the coastal Douglas-Fir and conservation partnership study area. University of British Columbia, British Columbia, pp. 26.

Natalia, M., \& Alie, M.M. (2014, in Indonesian). Coastal poverty assessment in Semarang City (case 
study: Tambak Lorok Fisherman Village). J Tek PMW, 3, 50-59.

Nicholls, R.J. (2002). Rising sea levels: potential impacts and responses. In: Hester, R.E., \& Harrison, R.M. (eds) Global Environmental Change. The Royal Society of Chemistry, pp 83108. doi: 10.1039/9781847550972-00083.

Nicholls, R.J., Marinova, N., Lowe, J.A., Brown, S., Vellinga, P., Gusmão, D de., Hinkel, J., \& Tol, R.S.J. (2011). Sea-level rise and its possible impacts given a "beyond $4^{\circ} \mathrm{C}$ world" in the twentyfirst century. Phil Trans $R$ Soc A, 369, 161-181. doi: $10.1098 /$ rsta.2010.0291.

Novianty, R., Sastrawibawa, S., \& Prihadi, D.J. (2012, in Indonesian). Identification of damages and rehabilitation efforts mangrove ecosystem in North Coast in the Subang Dustrict. J Fish Mar Sci, 3, 41-47. doi: 10.4135/9781412950589.n774.

Nusantara, M.A., Hutomo, M., \& Purnama, H. (2015). Evaluation and planning of mangrove restoration programs in Sedari Village of Kerawang District, West Java: Contribution of PHE-ONWJ Coastal Development Programs. Procedia Environ Sci, 23, 207-214. doi: 10.1016/j.proenv.2015.01.032.

Oppenheimer, M., Glavovic, B.C., Hinkel, J., Wal, R. van de., Magnan, A.K., Abd-Elgawad, A., Cai, R., Cifuentes-Jara, M., DeConto, R.M., Ghosh, T., Hay, J., Isla, F., Marzeion, B., Meyssignac, B., \& Sebesvari, Z. (2019). Chapter 4: Sea Level Rise and Implications for Low Lying Islands, Coasts and Communities [Pörtner, H.-O., Roberts, D.C., Masson-Delmotte, V., Zhai, M. Tignor, P., Poloczanska, E., Mintenbeck, K., Alegría, A., Nicolai, M., Okem, A., Petzold, J., Rama, B., \& Weyer, N.M. (eds.)]. IPCC Special Report on the Ocean and Cryosphere in a Changing Climate, Cambridge University Press, Cambridge, UK, pp 321-446.

Pasnin, O., Attwood, C., \& Klaus, R. (2016). Marine systematic conservation planning for Rodrigues Island, western Indian Ocean. Ocean \& Coastal Management, 130, 213-220. doi: 10.1016/j. ocecoaman.2016.06.014.

Peterson, G.D., Cumming, G.S., \& Carpenter, S.R. (2003). Scenario Planning: a Tool for Conservation in an Uncertain World. Conservation Biology, 17(2), 358-366. doi: 10.1046/j.1523-1739.2003.01491.x.

Ramadhany, A.S., Agus, D.S. A., \& Subardjo, P. (2012, In Indonesian). Coastal flood prone area in Semarang. J Mar Res, 1(2), 174-180. doi: 10.14710/jmr.v1i2.2035.

Rangel-Buitrago, N,. Williams, A.T., \& Anfuso, G. (2018). Hard protection structures as a principal coastal erosion management strategy along the Caribbean coast of Colombia. A chronicle of pitfalls. Ocean Coast Manag, 156, 58-75. doi: 10.1016/j.ocecoaman.2017.04.006.

Sala, E., Aburto-Oropeza, O., Paredes, G,. Parra, I., Barrera, J.C., \& Dayton, P.K. (2002). A general model for designing networks of marine reserves. Science, 298(5600), 1991-1993. doi: 10.1126/ science. 1075284 .

Sasmito, B., \& Suprayogi, A. (2017, in Indonesian). Coastal ecosystem vulnerability assessment in Demak district based on coastline change using remote sensing technology and geographic information system. Teknik, 38, 13-20. doi: 10.14710/teknik.v38n1.12181.

Setyawan, A.D., Winarno, K., \& Purnama, P.C. (2002, in Indonesian). Mangrove ecosystem in Java: 2. Restoration. Biodiversitas, 5, 105-118. doi: 10.13057/biodiv/d050212.

Singh, P., Kumar, A., \& Mishra, S. (2020). Performance evaluation of conservation plan for freshwater lakes in India through a scoring methodology. Environment, Development and Sustainability, 23, 3787-3810.

Siry, H.Y. (2018, in Indonesian). Policy and disaster mitigation in small islands [Presentation]. In: Diskusi Pojok Iklim, Tanggap Darurat Bencana Iklim. Ministry of Environment and Forestry, Jakarta, http://simlit.puspijak.org/files/other/ Bahan_Direktur_P4K_Ditjen_PRL_@_Pojok_ Iklim.pdf. Accessed 15 Oct $201 \overline{9}$.

Spalding, M.D., Mclvor, A., Tonneijck, F.H., Tol, S., \& van Eijk, P. (2014). Mangroves for coastal defense: guidelines for coastal managers and policy makers. Wageningen, The Netherlands, Wetlands International and The Nature Conservancy, http://www.nature.org/media/oceansandcoasts/ mangroves-for-coastal-defence.pdf. Accessed 15 Oct 2019.

Statistics of East Java Province. (2018, in Indonesia). East Java in Figures 2018. Statistics of East Java Province, Surabaya, https://jatim.bps.go.id/pu blication/2018/08/16/9999b727d316c006ee2fd 7e7/provinsi-jawa-timur-dalam-angka-2018.html. Accessed 15 Oct 2019.

Statistics of West Java Province. (2018, in Indonesian 
and English). West Java in Figures 2018. Statistics of West Java Province, Bandung, https://jabar.bps.go.id/publication/2018/08/16/ d8b96de222796402938666e4/provinsi-jawabarat-dalam-angka-2018.html. Accessed 15 Oct 2019.

Takashima, F. (2000). Silvofishery: an aquaculture system harmonized with the environment Silvofishery: an aquaculture system harmonized with the environment. In: Primavera, J.H., Garcia, L.M.B., Castaños, M.T., \& Surtida, M.B. (eds) Proceedings of the Workshop on MangroveFriendly Aquaculture organized by the SEAFDEC Aquaculture Department, January 11-15, 1999, Iloilo City, Philippines. Southeast Asian Fisheries Development Center, Aquaculture Department, Tigbauan, Iloilo, Philippines, 13-19.

Tonneijck, F., Winterwerp, H., Weesenbeeck, B. van., Bosma, R., Debrot, D., Noor, Y.R., \& Wilms, T. (2015). Building with Nature Indonesia Securing Eroding Delta Coastlines. Ecoshape, Dordecht, The Netherlands, https://edepot.wur.nl/377873. Accessed 15 Oct 2019.

Van-Oudenhoven, A.P., Siahainenia, A.J., Sualia, I., Tonneijck, F.H., van der Ploeg, S., de Groot, R.S., \& Leemans, R. (2015). Effects of different management regimes on mangrove ecosystem services in Java, Indonesia. Ocean \& Coastal Management, 116, 353-367.

Ward, P.J., Marfai, M.A., Yulianto, F., Hizbaron, D.R., \& Aerts, J.C.J.H. (2011). Coastal inundation and damage exposure estimation: a case study for Jakarta. Nat Hazards, 56, 899-916. doi: 10.1007/ s11069-010-9599-1.

Williams, A.T., Rangel-Buitrago, N., Pranzini, E., \& Anfuso, G. (2018). The management of coastal erosion. Ocean Coast Manag, 156, 4-20. doi: 10.1016/j.ocecoaman.2017.03.022.

Wilson, K.A., Cabeza, M., \& Klein, C.J. (2009). Fundamental concepts of spatial conservation prioritization. Spatial conservation prioritization: quantitative methods and computational tools. Oxford University Press, New York, 16-27.

Wouthuyzen, S., Melati, F., Fachrul, B., Hakim, R., Hukom, F.D., \& Purnama, H. (2014). Long-term monitoring of Mangroves conversion along the Nothern Coast of West Java Province, Indonesia using multi-temporal Landsat satellite images. In: GISUP2014 (International) The 16th International Symposium of Geospatial Information Science and Urban Planning. pp 3-13 https://hdl.handle.
net/20.500.12690/RIN/PH3UOK. Accessed 15 Oct 2019.

Yasuhara, K., Komine, H., Yokoki, H., Suzuki, T., Mimura, N., Tamura, M., \& Chen, G. (2011). Effects of climate change on coastal disasters: New methodologies and recent results. Sustain Sci 6, 219-232. doi: 10.1007/s11625-011-0127-3. 